TP Periodica Polytechnica Mechanical Engineering

62(3), pp. 187-195, 2018

https://doi.org/10.3311/PPme.11213

Creative Commons Attribution (i)

RESEARCH ARTICLE

\section{Theoretical Analysis of Continuous Heat Extraction from Absorber of Solar Still for Improving the Productivity}

Elsayed El-Agouz ${ }^{1}$, Abd Elnaby Kabeel ${ }^{1}$, Jothirathinam Subramani², A. Muthu Manokar ${ }^{3}$, Thirugnanasambantham Arunkumar ${ }^{4}$, Ravishankar Sathyamurthy ${ }^{1,2^{*}}$, Parasumanna Krishnamurthy Nagarajan $^{2}$, Devarajan Magesh $\mathrm{Babu}^{2}$

Received 01 July 2017; accepted after revision 17 February 2018

\begin{abstract}
This paper communicates the theoretical analysis of continuous waste heat extraction from the other side of absorber plate. For theoretical analysis two conditions are determined one is the mass of water in the absorber and another one is mass flow rate of water around the absorber plate. Results indicated that the water temperature is reached maximum at $10 \mathrm{~kg}$ of mass and $5 \mathrm{~kg} / \mathrm{hr}$ mass flow of water and the heat extracted from the absorber is higher at optimum mass flow of $5 \mathrm{~kg} / \mathrm{hr}$. Also, the higher temperature difference between the water and the collector cover is found during the off-shine period. The maximum achievable hourly productivity of 0.9 and $0.5 \mathrm{~kg}$ is found for the solar still with and without circulation respectively. The yield from present model with continuous heat extraction is increased from 3 to $5.5 \mathrm{~kg} / \mathrm{m}^{2}$. As the approached method is more new to the society it may be determined by AgouzNagarajan-Sathyamurthy (ANS) model.
\end{abstract}

\section{Keywords}

continuous extraction, waste heat, absorber, solar still, improved yield

\footnotetext{
${ }^{1}$ Mechanical Power Engineering Department, Faculty of Engineering,

Tanta University, El-Geish Street, Gharbia, Tanta, Egypt

${ }^{2}$ Department of Mechanical Engineering, S.A. Engineering College, Chennai-600077, Tamil Nadu, India

${ }^{3}$ Department of Mechanical Engineering,

Kamaraj College of Engineering and Technology,

Virudhunagar, Tamil Nadu, India

${ }^{4}$ Institute for Energy Studies, Anna University,

Chennai-600025, Tamil Nadu, India

*Corresponding author, e-mail: ravishankars@saec.ac.in
}

\section{Introduction}

Greater growth of population and industries results in shortage of fresh water. Earth is almost covered with a larger water source and smaller land mass. People used to drink large amount of water for their thirsty need. Water available in the form of rivers, lakes cannot be consumed directly without pre-processing, as these need some purification process in order to remove bacteria and undissolved salts. In early days the possible method of getting pure water is heating the brackish water and condensing them back to get fresh water by burning fossil fuels. Due to the exhaustion of coal, crude oil and increases in global warming, the evolution of using renewable energy for getting fresh water evolved during the late 20th century. One of the best energy source applied is solar energy. Source of energy from sun is mostly environmental friendly and non polluting clean energy source. Basin type still is the most aged process of producing fresh water [1-10]. The fresh water conversion rate from the solar still system is predominantly depends on the solar intensity. The basin water temperature increases continuously due to heat energy emitted from the sun in the form of solar intensity. After reaching the boiling point of water, the water evaporates and it condenses on the solar still condenser cover. The various techniques employed in solar still, to raise the temperature of water and hence increases the productivity was studied from the detailed literatures reviews of Ravishankar et al. [11], Kabeel et al. [12] and Manokar et al. [1315]. From the detailed literature studies it is clear that water temperature can be improved by either feeding waste warm water or pre heat the water by incorporating the different solar collectors or concentrators. Gupta et al. [16] theoretically analyzed the intermittent flow of waste warm water to the double basin solar still similarly same analyses was done by Yadav et al. in single basin solar still [17]. Sodha et al. [18] and Tiwari et al. [19] experimentally investigated the performance of solar still utilizing the warm water from the industry. Tiwari et al. [20] keep up a higher temperature difference between the water and collector cover by increasing the water temperature by flowing waste hot water in the basin and decrease the collector cover temperature by flowing the cold water above the surface of collector cover. This would results in increase in both evaporation and condensation 


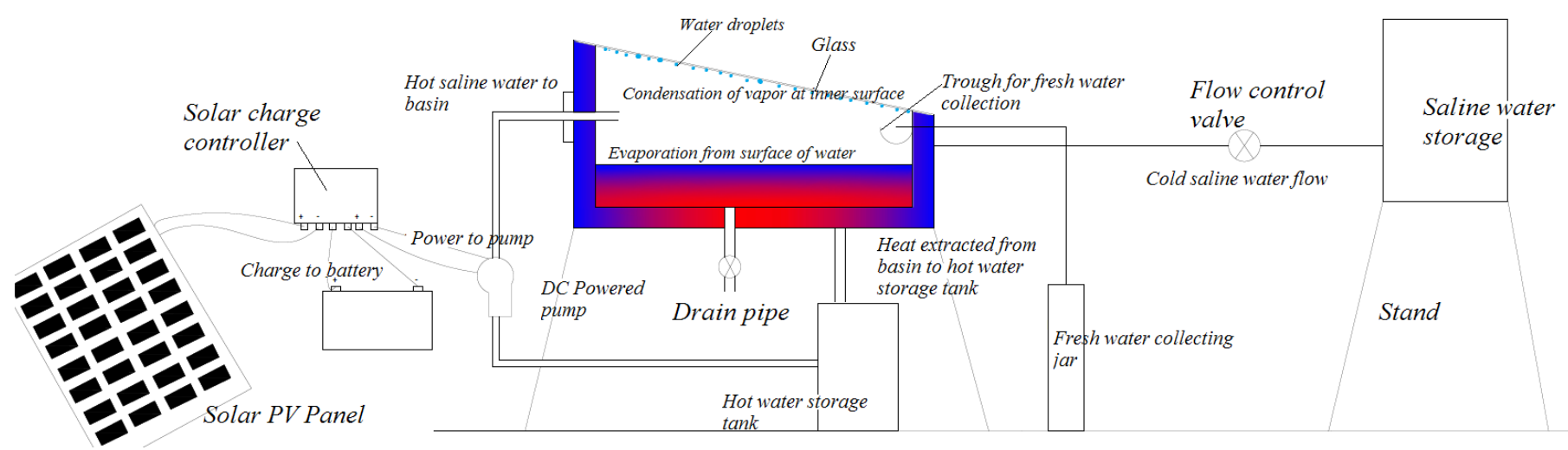

Fig. 1 Schematic diagram of single slope solar still with continuous extraction of heat from basin

rate and hence higher yield. Sinha and Tiwari [21] identified a new solar still by coupling concentrating parabolic collector to a solar still. Similarly B. Prasad and Tiwari [22] analysed a dual basin solar still with Flat Plate Collector (FPC). Extensive studies are also carried out on single slope solar still by reflecting the solar radiation through the bottom absorber as inverted basin studied by Dev et al. [23] and Suneja et al. [24, 25]. Several researchers investigated the integration of active solar still with FPC [26-34], Compound Parabolic Concentrator [35-38], Parabolic shaped concentrator [39], Parabolic Trough collector [40, 41], Cylindrical parabolic concentrator [42, 43], Evacuated Tube Collector [44-47], Parabolic Dish concentrator [10, 48, 49], Concentrator with crescent absorber [50], Solar pond [51-54], Solar still integration [55-57], Hybrid PV/T integrated solar still [58-60] for improving the yield.

In the previous studies, cover cooling technique was used to improve the condensation rate and yield from the solar still and hence only $5 \%$ of the heat was recoverable. The maximum amount of heat utilized by water and absorber were found to be $5 \%$ and $90 \%$ respectively. In this work a novel method is identified by circulating water around the basin to extract the waste heat. Also, in the present study water mass $\left(\mathbf{M}_{\mathbf{w}}\right)$ inside the basin and flow rate of water $\left(\mathbf{M}_{\mathbf{f}}\right)$ around the basin were optimized for better improvement in fresh water yield.

\section{Methodology}

Fig. 1 shows the schematic drawing of a novel method system with continuous extraction of waste heat around the basin. In the present method water is initially fed around the basin instead of feeding it directly into the basin. The inlet water flow is controlled by via flow control valve. With the help PV Powered DC pump water is re-circulated into the still basin. Insulation can be provided around the basin for reducing the heat loss to the surroundings. Excess water can be drained from the basin with the provision provided at the bottom of basin. Glass trough is used to collect the condensate water and it is measured by using fresh water collecting jar. Table 1 shows the parameters used for theoretical analysis. Also, Environmental parameters used for theoretical calculation is given in Fig. 2.
Table 1 Parameters for theoretical investigation

\begin{tabular}{cccc}
\hline Parameter & Value & Parameter & Value \\
\hline $\mathrm{A}_{\mathrm{b}}$ & $1 \mathrm{~m}^{2}$ & $\tau_{\mathrm{g}}$ & 0.9 \\
$\mathrm{~A}_{\mathrm{g}}$ & $1 \mathrm{~m}^{2}$ & $\tau_{\mathrm{W}}$ & 0.95 \\
$\alpha_{\mathrm{b}}$ & 0.9 & $\mathrm{Y}$ & $40 \mathrm{~g} / \mathrm{kg}$ \\
$\alpha_{\mathrm{w}}$ & 0.05 & $\alpha_{\mathrm{g}}$ & 0.05 \\
\hline
\end{tabular}

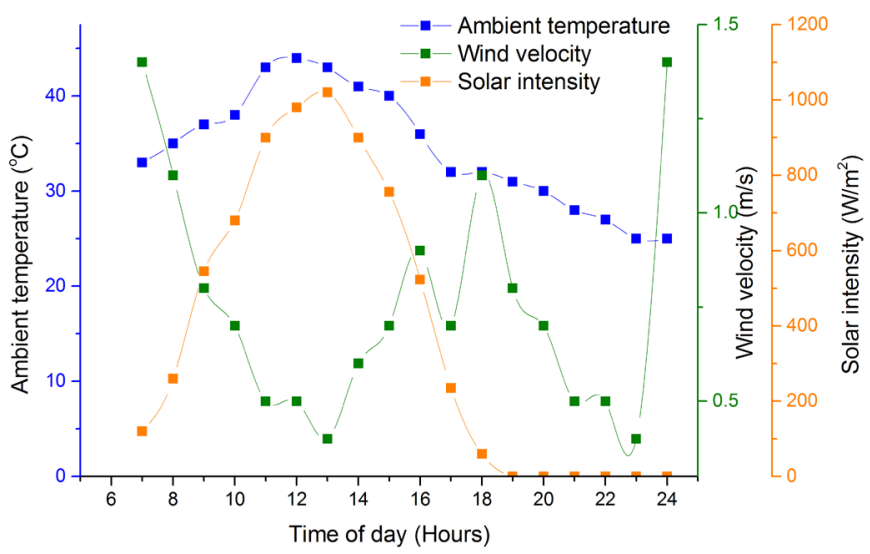

Fig. 2 Variation of ambient temperature, wind velocity and solar intensity

\section{Theoretical approach}

The basin temperature is determined as,

$$
\begin{gathered}
I(t) \tau_{g} \tau_{w} \alpha_{b}=h_{1}\left(T_{b}-T_{w}\right)+U_{b}\left(T_{b}-T_{a}\right) \\
T_{b}=\frac{I(t) \tau_{g} \tau_{w} \alpha_{b}+h_{1} T_{w}-U_{b} T_{a}}{h_{1}+U_{b}}
\end{gathered}
$$

$\mathrm{h}_{1}=109 \mathrm{~W} / \mathrm{m}^{2} \mathrm{~K}[60]$ and $\mathrm{U}_{\mathrm{b}}=14 \mathrm{~W} / \mathrm{m}^{2} \mathrm{~K}$ [61].

The outlet water temperature is determined as,

$$
T_{w o}=\frac{I(t) \tau_{g} \tau_{w} \alpha_{b}-Q_{c, b-w}+h_{c g-a}\left(T_{b}-T_{a}\right)}{m_{f} C_{p(w)}}+T_{w i} .
$$

The water temperature is determined as [66-68],

$$
T_{w(b a \sin )}=\frac{f(t)}{a}\left[1-e^{\frac{-a t}{M_{e q u}}}\right]+T_{w, j}\left[e^{\frac{-a t}{M_{\text {equ }}}}\right] .
$$


Where " $f(t)$ ", " $a$ " and " $M_{\text {equ }}$ " values are

$$
\begin{gathered}
f(t)=I(t) \tau_{g} \alpha_{w}+\left[\frac{I(t) \tau_{g} \tau_{w} \alpha_{b}+U_{b} T_{a}}{\left(1+\frac{U_{b}}{h_{1}}\right)}\right] \\
+\left[\frac{I(t) \alpha_{g}+h_{r g s} T_{s}+h_{c g a} T_{a}}{\left(1+\frac{h_{3}}{h_{2}}\right)}\right] \\
a=\left[\frac{h_{1} U_{b}}{h_{1}+U_{b}}\right]+\left[\frac{h_{2} h_{3}}{h_{2}+h_{3}}\right] \\
M_{\text {equ }}=m_{w} \times C_{p(w)} .
\end{gathered}
$$

Also,

$$
d T_{w}=\frac{\left(I(t) \alpha_{w}+Q_{f w}\right) * d t}{m_{w} C_{p(w)}} .
$$

Simplifying for basin water temperature after feeding hot water temperature with water maintained in basin, the temperature of water is given by,

$$
T_{w}=d T_{w}+T_{w, b a s i n} .
$$

The specific heat capacity of saline water is determined as $[53,62-65]$,

$$
C_{p(w)}=a_{1}+a_{2} T_{w}+a_{3} T_{w}^{2}+a_{4} T_{w}^{3} .
$$

Where, $a_{1}, a_{2}, a_{3}$ and $a_{4}$ value are

$$
\begin{gathered}
a_{1}=4206.8+6.6197 Y+1.2288 \times 10^{-2} Y^{2} \\
a_{2}=-1.1262+5.4178 \times 10^{-2} Y-2.2719 \times 10^{-6} Y^{2} \\
a_{3}=1.2026 \times 10^{-2}-5.5366 \times 10^{-4} Y+1.8906 \times 10^{-6} Y^{2} \\
a_{4}=6.8874 \times 10^{-7}+1.517 \times 10^{-6} Y-4.4268 \times 10^{-9} Y^{2} .
\end{gathered}
$$

Where $Y$ is the salinity level in water $C_{p(w)}=$ The seawater specific heat at constant pressure expressed as $\mathrm{J} / \mathrm{kg} \mathrm{K}$.

The glass temperature is determined as,

$$
\begin{gathered}
I(t) \alpha_{g}=h_{3}\left(T_{g}-T_{a}\right)-h_{2}\left(T_{w}-T_{g}\right) \\
T_{g}=\frac{I(t) \alpha_{g}+h_{2} T_{w}+h_{3} T_{a}}{h_{2}+h_{3}} .
\end{gathered}
$$

Where,

$$
h_{2}=h_{c, w-g}+h_{e, w-g}+h_{r, w-g} .
$$

Convective heat transfer coefficient is determined as [60],

$$
h_{c, w-g}=0.884\left[\left(T_{w}-T_{g}\right)+\frac{\left(T_{w}+273.15\right)\left(p_{w}-p_{g}\right)}{\left(268900-p_{w}\right)}\right]^{1 / 3} \text {. }
$$

The values of partial pressure equation in given by,

$$
\begin{aligned}
& p_{w}=e^{\left(25.314-\frac{5144}{T_{w}+273.15}\right)} \\
& p_{g}=e^{\left(25.314-\frac{5144}{T_{g}+273.15}\right)} .
\end{aligned}
$$

The evaporative heat transfer coefficient is determined as [61],

$$
h_{e, w-g}=16.27 \times 10^{-3} h_{c, w-g}\left[\frac{\left(p_{w}-p_{g}\right)}{\left(T_{w}-T_{g}\right)}\right] .
$$

Radiative heat transfer coefficient is determined as [60],

$$
\begin{gathered}
h_{r, w-g}=\varepsilon_{\text {effective }} \sigma\left[\left(T_{w}+273.15\right)^{2}+\left(T_{g}+273.15\right)^{2}\right] \\
{\left[T_{w}+T_{g}+546.3\right]}
\end{gathered}
$$

$$
\varepsilon_{\text {effective }}=\left(\frac{1}{\varepsilon_{g}}+\frac{1}{\varepsilon_{w}}-1\right)^{-1} .
$$

And

$$
h_{3}=h_{c, g-a}+h_{r, g-a} .
$$

Convection between glass and ambient is determined as [60],

$$
h_{c, g-a}=5.7+3.8 u \text {. }
$$

And radiative heat transfer coefficient between glass and ambient is determined as [60],

$$
\begin{aligned}
h_{r, g-a}= & \varepsilon_{\text {effective }} \sigma\left[\left(T_{g}+273.15\right)^{2}+\left(T_{a}+273.15\right)^{2}\right] \\
& {\left[T_{g}+T_{a}+546.3\right] . }
\end{aligned}
$$

\section{Results and Discussions}

Fig. 3 (a), (b) and (c) shows the variation of water, basin and collector cover temperature of modified still with continuous flow of water around the basin for complete heat extraction by changed the $\mathbf{M}_{\mathbf{w}}$ from 10 to $50 \mathrm{~kg}$. From the theoretical analysis, it is found that the maximum temperature of water, basin and collector cover were found as 110,120 and $107^{\circ} \mathrm{C}$ respectively at a $\mathbf{M}_{\mathbf{w}}$ of $20 \mathrm{~kg}$ and with a continuous constant $\mathbf{M}_{\mathbf{f}}$ of $5 \mathrm{~kg} / \mathrm{hr}$ around the basin. During the morning hours the heat gained by lower $\mathbf{M}_{\mathbf{w}}$ has the highest temperature, whereas, heat thermal energy is stored in the saline water with higher $\mathbf{M}_{\mathbf{w}}$. During the afternoon with a drop off solar intensity, the temperature of water decreased quickly at lower mass. The water temperature increase with increased $\mathbf{M}_{\mathbf{w}}$ as it is due to the storage of thermal energy by saline water inside the basin.

It is observed that the optimal $\mathbf{M}_{\mathbf{w}}$ in the basin is $20 \mathrm{~kg}$ as it produced the maximum water temperature. Fig. 4 shows the variation of temperature difference between the water and the 

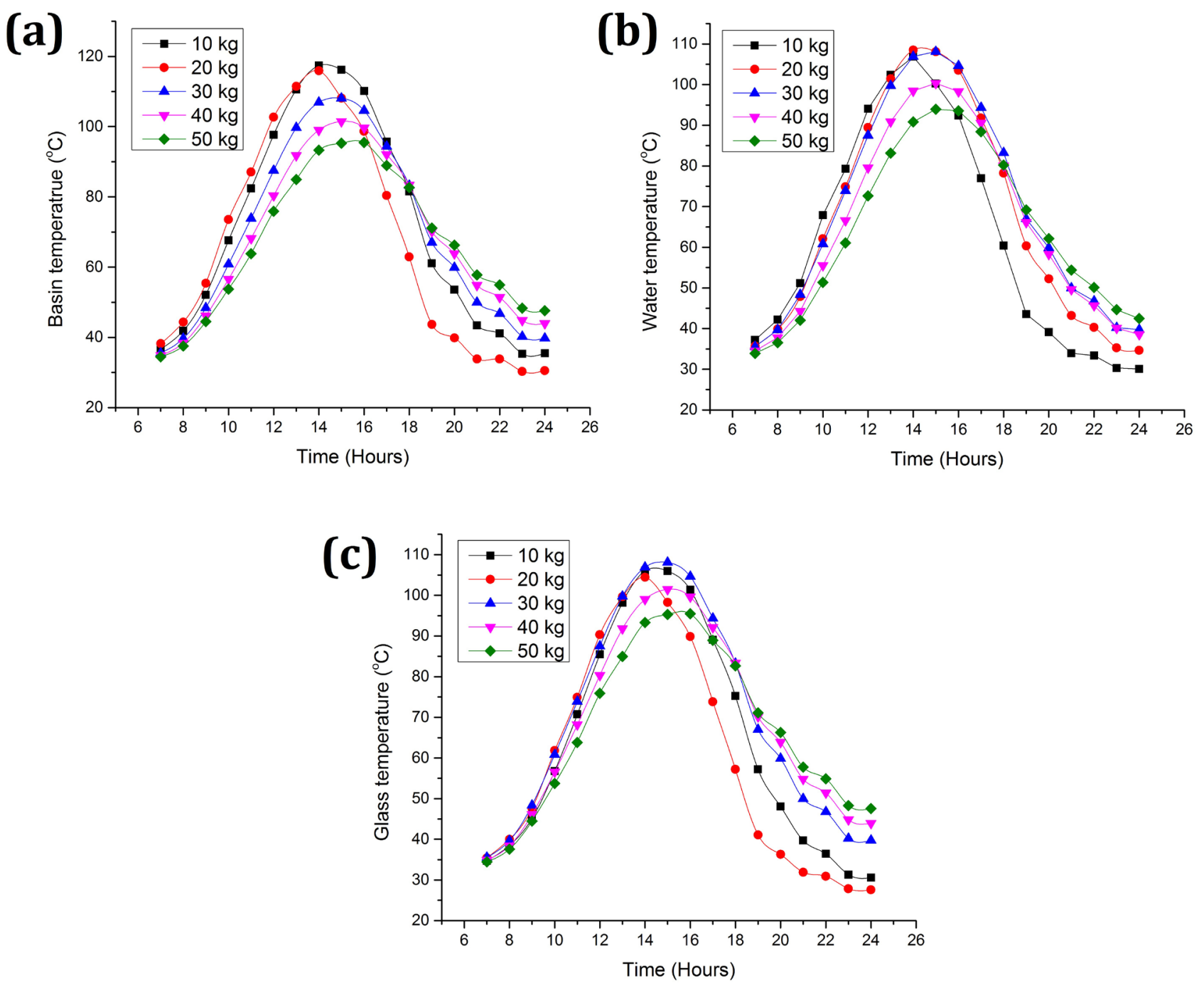

Fig. 3 Hourly variation of (a) Basin (b) Water and (c) Glass temperature under different water mass and constant water flow around the basin

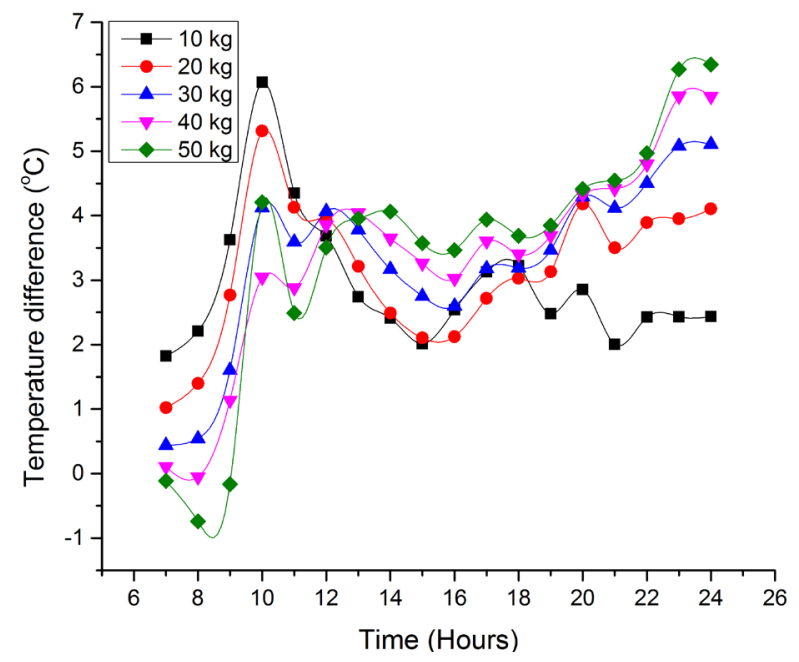

Fig. 4 Hourly variation of temperature difference between water and glass

collector cover. With an increased mass of water, the temperature difference is lower in the morning hours. It is also observed that from $7 \mathrm{AM}$ to $9 \mathrm{AM}$ there is a negative value in the temperature difference. This clearly indicates that thermal energy is stored in the saline water at higher $\mathbf{M}_{\mathbf{w}}$. The $\mathbf{M}_{\mathbf{w}}$ with $10 \mathrm{~kg}$ has the maximum temperature difference during the sunshine hours and falling thereafter as the solar intensity is decreasing. The maximum temperature difference of $6.2^{\circ} \mathrm{C}, 5.5^{\circ} \mathrm{C}, 4^{\circ} \mathrm{C}$, $3{ }^{\circ} \mathrm{C}$ and $2.5^{\circ} \mathrm{C}$ is obtained between the water and the collector cover during the off shine period with $\mathbf{M}_{\mathbf{w}}=50 \mathrm{~kg}, \mathbf{M}_{\mathbf{w}}=40 \mathrm{~kg}$, $\mathbf{M}_{\mathbf{w}}=30 \mathrm{~kg}, \mathbf{M}_{\mathbf{w}}=20 \mathrm{~kg}$ and $\mathbf{M}_{\mathbf{w}}=10 \mathrm{~kg}$ respectively.

Fig. 5 shows the variation of yield from solar still under different $\mathbf{M}_{\mathbf{w}}$ with a constant $\mathbf{M}_{\mathbf{f}}$ of $5 \mathrm{~kg} / \mathrm{hr}$ around the basin. It is found that the productivity of water under $\mathbf{M}_{\mathbf{w}}=20 \mathrm{~kg}$ is higher and the maximum value is found to be $0.9 \mathrm{~kg}$. Similarly the fresh water yield from $\mathbf{M}_{\mathbf{w}}=10 \mathrm{~kg}$ is lesser during the off shine period and decreases by $86 \%$ as compared with $\mathbf{M}_{\mathbf{w}}=50 \mathrm{~kg}$. As previously it is clearly discussed in the previous literatures, the energy storage by saline water increases the productivity and the optimum $\mathbf{M}_{\mathbf{w}}$ is found as $20 \mathrm{~kg}$. The percentage difference between the yield of fresh water produced during off shine period with increase in $\mathbf{M}_{\mathbf{w}}$ from 20,30, 40 and $50 \mathrm{~kg}$ are found as $10,12.5,20$ and $26 \%$ respectively.

Fig. 6 (a), (b) and (c) shows the variations of water, basin and collector cover temperature of continuous water circulation around the basin with constant mass at different flow rate. It is found that the temperature of water without circulation is 


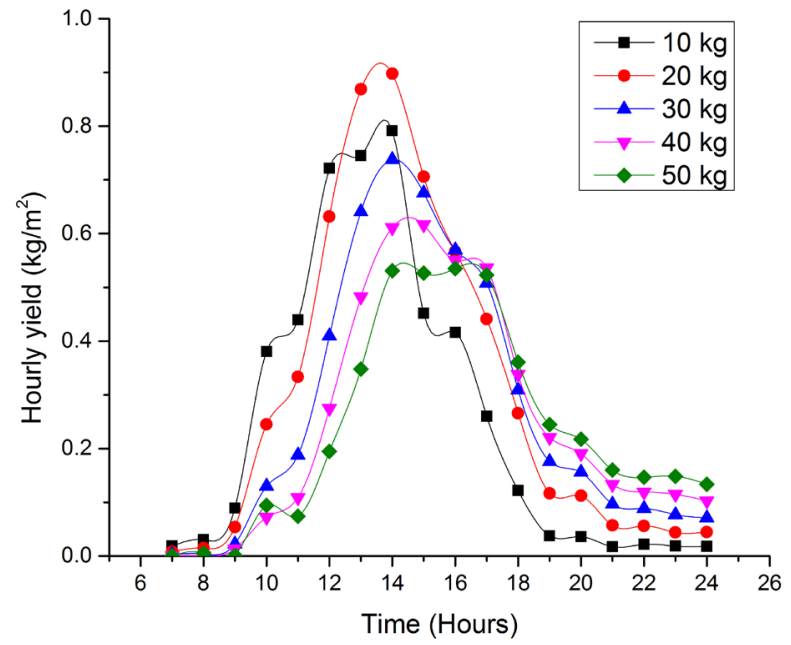

Fig. 5 Hourly variation of yield at different water mass with constant mass flow around basin

lower (27.27\% decrease) as compared to continuous flow. The maximum water temperature is obtained at the $\mathbf{M}_{\mathrm{f}}=5 \mathrm{~kg} / \mathrm{hr}$. At lower flow rate, water absorbs the maximum amount of heat and furthermore increase in its temperature is not possible. While at the higher flow rate of saline water, the gaining of heat from the basin will be higher. From Fig. 6 (b) it is found that the temperature of basin is higher and maximum $\left(120^{\circ} \mathrm{C}\right)$, as the heated water is feed into the basin and there is a larger possibility in rejection of heat to the surrounding. With these convection layer is formed between water-basin and basin-flowing water.

Due to the continuous evaporation of vapour inside the basin of solar still, the temperature of inner cover rises. It is found that, a maximum temperature difference of $5{ }^{\circ} \mathrm{C}$ with a deviation of $5-10 \%$ is achieved for all cases (Fig. 7). In the off shine time the maximum temperature difference for $\mathbf{M}_{\mathrm{f}}$ of $5 \mathrm{~kg} / \mathrm{hr}$ is found as $6^{\circ} \mathrm{C}$ with a maximum yield of $0.2 \mathrm{~kg} / \mathrm{m}^{2}$. By extracting the remaining heat from the basin the productivity of the system is improved by $78 \%$ than the still without heat extraction.

Fig. 8 shows the variation of productivity from the solar still with and without flow of water around the basin at constant $\mathbf{M}_{\mathbf{w}}$ of $20 \mathrm{~kg}$ in the basin. Due to the continuous flow and heat extraction, the productivity of fresh water is improved by 28 and $52 \%$ with constant $\mathbf{M}_{\mathrm{f}}$ of 2.5 and $5 \mathrm{~kg} / \mathrm{hr}$ respectively around the basin. The peak yield from solar still with $\mathbf{M}_{\mathbf{f}}$ of 2.5 and $5 \mathrm{~kg} / \mathrm{hr}$ were found to be 0.7 and $0.9 \mathrm{~kg} / \mathrm{hr}$ respectively.
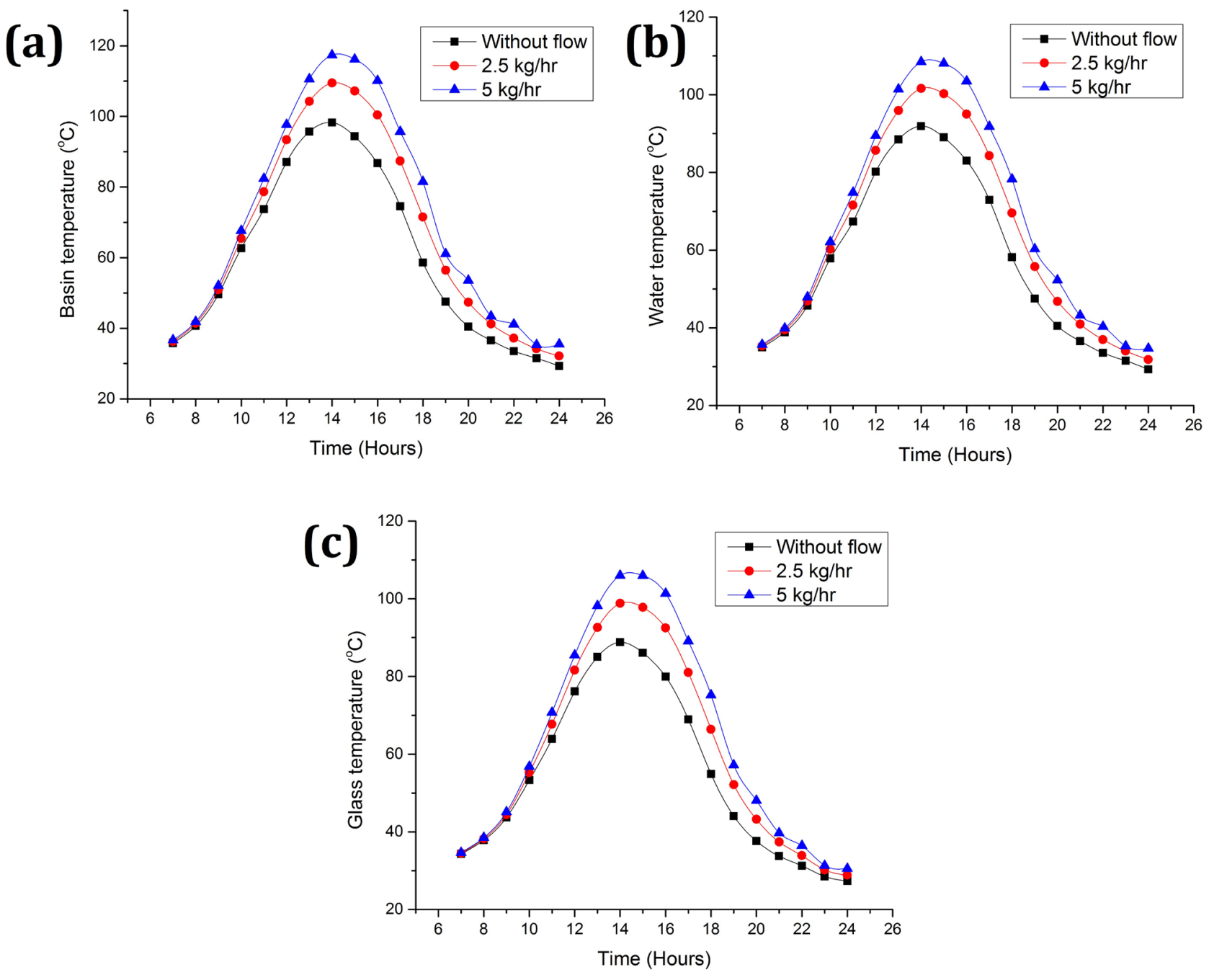

Fig. 6 Hourly variation of (a) basin, (b) water, and (c) glass temperature with different mass flow around the basin and constant water mass (mw $=20 \mathrm{~kg}$ ) 


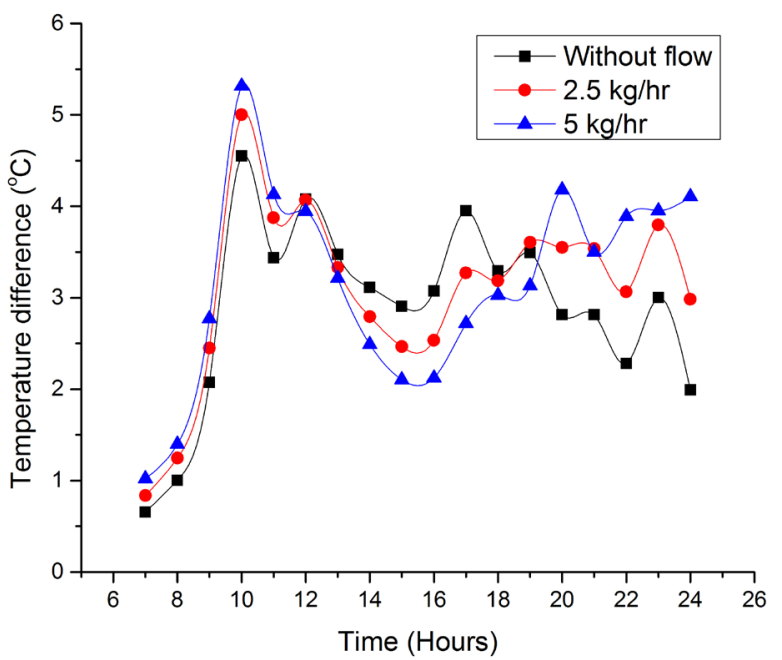

Fig. 7 Hourly variation of temperature difference between water and glass $(\mathrm{mw}=20 \mathrm{~kg})$

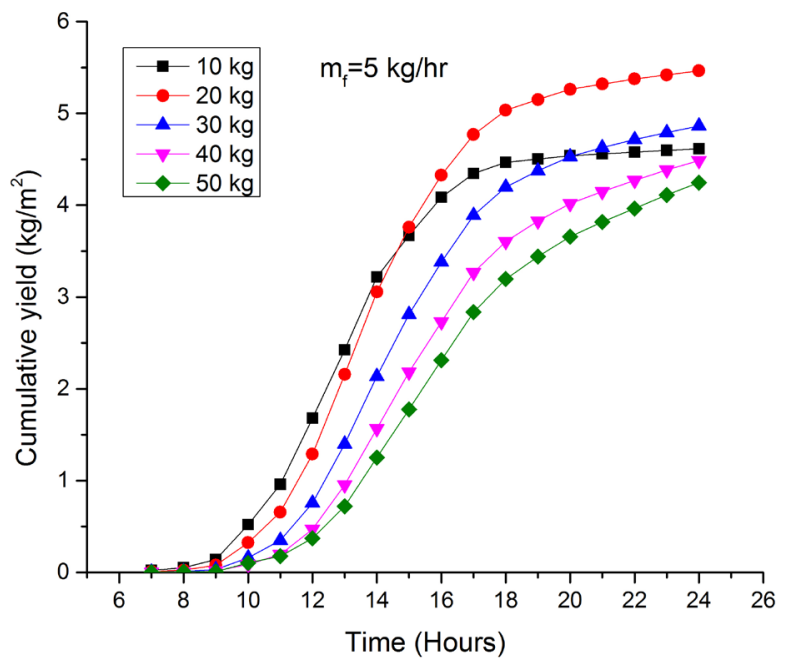

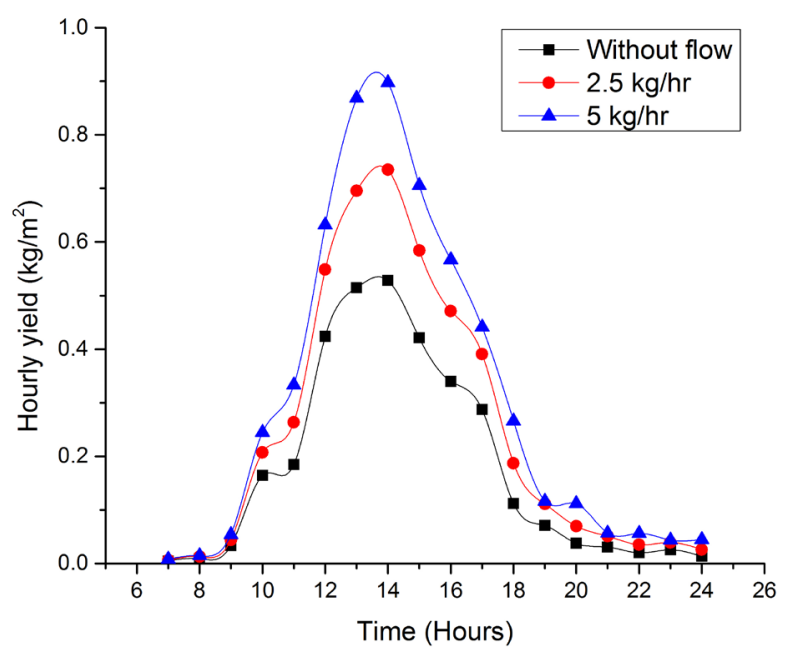

Fig. 8 Hourly variation of yield with different mass flow around the basin $(\mathrm{mw}=20 \mathrm{~kg})$

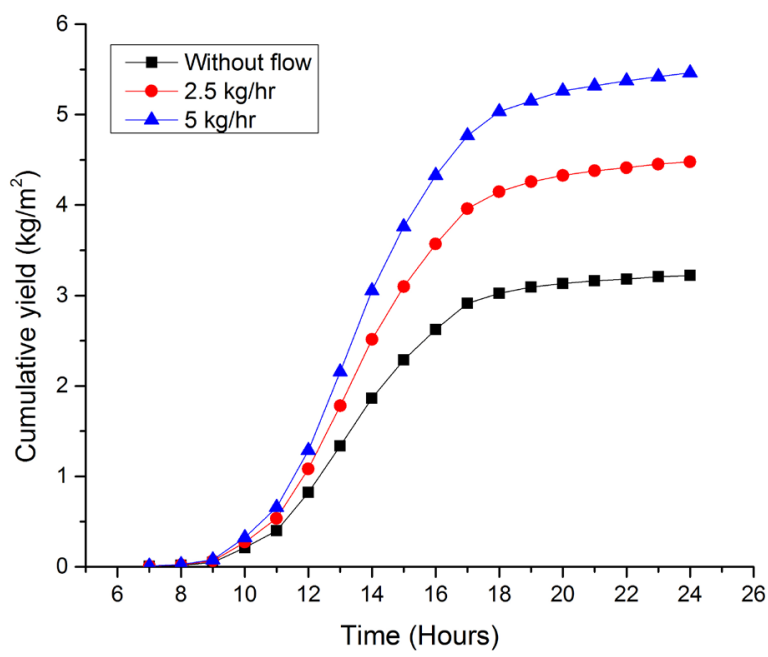

Fig. 9 (a) Variation of cumulative yield from modified solar still with different water mass and constant water flow around the basin

(b) Variation of cumulative yield from modified solar still with constant water mass and different water flow around the basin

Fig. 9 (a) and (b) shows the total accumulated productivity from the new modified solar still under different $\mathbf{M}_{\mathbf{w}}$ and different flow rates in the basin. It is found that the fresh water production is maximum at $\mathbf{M}_{\mathbf{w}}$ of $20 \mathrm{~kg}$ and with a $\mathbf{M}_{\mathbf{f}}$ of $5 \mathrm{~kg} / \mathrm{hr}$. The optimized $\mathbf{M}_{\mathbf{w}}$ and $\mathbf{M}_{\mathbf{f}}$ is identified as $20 \mathrm{~kg}$ and $5 \mathrm{~kg} / \mathrm{hr}$ respectively.

\section{Conclusions}

From the present theoretical study the following identifications are arrived:

- Instead of using parabolic trough collector and flat plate collector nearly $50 \%$ of energy can be recovered from the present model with continuous circulation of water around the basin.

- The yield of continuous waste heat extraction from an absorber of solar still was improved from 3 to $5.5 \mathrm{~kg} / \mathrm{m}^{2}$.
- Water temperature inside the basin is higher in the case of $\mathrm{m}_{\mathrm{w}}=50 \mathrm{~kg}$ during the off-shine period with a constant circulation of water around the basin $\left(\mathrm{m}_{\mathrm{f}}=5 \mathrm{~kg} / \mathrm{hr}\right)$.

- Temperature difference between the saline water and glass was negative for $\mathrm{m}_{\mathrm{w}}=40$ and $50 \mathrm{~kg}$ and showing that energy is stored in the saline water.

- The optimized $\mathbf{M}_{\mathrm{f}}$ and $\mathbf{M}_{\mathbf{w}}$ in the basin is found as $5 \mathrm{~kg} / \mathrm{hr}$ and $20 \mathrm{~kg}$ respectively.

\section{Nomenclature}

FPC Flat Plate Collector

$\mathrm{M}_{\mathrm{w}} \quad$ Water mass

$\mathrm{M}_{\mathrm{f}} \quad$ flow of water 


\section{References}

[1] Nagarajan, P. K., Subramani, J., Suyambazhahan, S., Sathyamurthy, R. "Nanofluids for solar collector applications: a review." Energy Procedia. 61, pp. 2416-2434. 2014. https://doi.org/10.1016/j.egypro.2014.12.017

[2] Sathyamurthy, R., Nagarajan, P. K., El-Agouz, S. A., Jaiganesh, V., Sathish Khanna, P. "Experimental investigation on a semi-circular trough-absorber solar still with baffles for fresh water production." Energy Conversion and Management. 97, pp. 235-242. 2015. https://doi.org/10.1016/j.enconman.2015.03.052

[3] Sathyamurthy, R., El-Agouz, S. A., Vijayakumar, D. "Experimental analysis of a portable solar still with evaporation and condensation chambers." Desalination. 367, pp. 180-185. 2015. https://doi.org/10.1016/j.desal.2015.04.012

[4] Nagarajan, P. K., Vijayakumar, D., Paulson, V., Chitharthan, R. K., Narashimulu, Y., Ramanarayanan, Sathyamurthy, R. "Performance evaluation of triangular pyramid solar still for enhancing productivity of fresh water." Research Journal in Pharmaceutical, Biological and Chemical Sciences. 5(2), pp. 764-771. 2014.

[5] Sathyamurthy, R.,Kennady H. J., Nagarajan, P. K., Ahsan, A. "Factors affecting the performance of triangular pyramid solar still." Desalination. 344, pp. 383-390. 2014.

https://doi.org/10.1016/j.desal.2014.04.005

[6] Sathyamurthy, R., Nagarajan, P. K., Kennady, H. J., Ravikumar, T. S., Paulson, V., Ahsan, A. "Enhancing the heat transfer of triangular pyramid solar still using phase change material as storage material." Frontiers in Heat and Mass Transfer (FHMT). 5(1), pp. 1-5. 2014.

https://doi.org/10.5098/hmt.5.3

[7] Sathyamurthy, R., Nagarajan, P. K., Subramani, J., Vijayakumar, D., Mohammed Ashraf Ali, K. "Effect of water mass on triangular pyramid solar still using phase change material as storage medium." Energy Procedia. 61, pp. 2224-2228. 2014.

https://doi.org/10.1016/j.egypro.2014.12.114

[8] Sathyamurthy, R., Nagarajan, P. K., Vijayakumar, D., Jawahar, M. K. "Phase change material on augmentation of fresh water production using pyramid solar still." International Journal of Renewable Energy Development (IJRED). 2(3), pp. 115-120. 2013.

[9] Sathyamurthy, R., Harris Samuel, D. G., Nagarajan, P. K. "Theoretical analysis of inclined solar still with baffle plates for improving the fresh water yield." Process Safety and Environmental Protection. 101, pp. 93-107. 2016. https://doi.org/10.1016/j.psep.2015.08.010

[10] Arunkumar, T., Denkenberger, D., Velraj, R., Sathyamurthy, R., Tanaka, H., Vinothkumar, K. "Experimental study on a parabolic concentrator assisted solar desalting system." Energy Conversion and Management. 105, pp. 665-674. 2015. https://doi.org/10.1016/j.enconman.2015.08.021

[11] Sathyamurthy, R., El-Agouz, S. A., Nagarajan, P. K., Subramani, J., Arunkumar, T., Mageshbabu, D., Madhu, B., Bharathwaaj, R., Prakash, N. "A Review of integrating solar collectors to solar still." Renewable and Sustainable Energy Reviews. 77, pp. 1069-1097. 2017. https://doi.org/10.1016/j.rser.2016.11.223

[12] Kabeel, A. E., Arunkumar, T., Denkenberger, D. C., Sathyamurthy, R. "Performance enhancement of solar still through efficient heat exchange mechanism-a review." Applied Thermal Engineering. 114, pp. 815-836. 2017.

https://doi.org/10.1016/j.applthermaleng.2016.12.044
[13] Manokar, A. M., Murugavel, K. K., Esakkimuthu, G. "Different parameters affecting the rate of evaporation and condensation on passive solar still-A review." Renewable and Sustainable Energy Reviews. 38, pp. 309-322. 2014.

https://doi.org/10.1016/j.rser.2014.05.092

[14] Manokar, A. M., Winston, D. P.,Kabeel, A. E., Sathyamurthy, R., Arunkumar, T. "Different parameter and technique affecting the rate of evaporation on active solar still - a review." Heat and Mass Transfer. 54(3), pp. 593-630. 2017.

https://doi.org/10.1007/s00231-017-2170-9

[15] Manokar, A. M., Winston, D. P., Kabeel, A. E., El-Agouz, S. A., Sathyamurthy, R., Arunkumar, T., Madhu, B., Ahsan, A. "Integrated PV/T solar still-a mini-review." Desalination. 435, pp. 259-267. 2018. https://doi.org/10.1016/j.desal.2017.04.022

[16] Gupta, R. A., Rai, S. N., Tiwari, G. N. "Transient analysis of double basin solar still with intermittent flow of waste hot water in night." Energy Conversion and Management. 28(3), pp. 245-249. 1988. https://doi.org/10.1016/0196-8904(88)90030-1

[17] Yadav, Y. P., Kumar, A. "Transient analytical investigations on a single basin solar still with water flow in the basin." Energy Conversion and Management. 31(1), pp. 27-38. 1991. https://doi.org/10.1016/0196-8904(91)90102-O

[18] Sodha, M. S. Kumar, A.,Tiwari, G. N. "Utilization of waste hot water for distillation." Desalination. 37(3), pp. 325-342. 1991. https://doi.org/10.1016/S0011-9164(00)88656-7

[19] Tiwari, G. N. "Performance of solar still with intermittent flow of waste hot water in the basin." Desalination. 52(3), pp. 345-357. 1985. https://doi.org/10.1016/0011-9164(85)80044-8

[20] Tiwari, G. N., Garg, H. P. "Effect of water flow over the glass cover of a single basin solar still with an intermittent flow of waste hot water in the basin." Energy Conversion and Management. 25(3), pp. 315-322. 1985. https://doi.org/10.1016/0196-8904(85)90049-4

[21] Sinha, S., Tiwari, G. N. "Thermal evaluation of concentrator-assisted solar distillation system." Heat Recovery Systems and CHP. 12(6), pp. 481-488. 1992. https://doi.org/10.1016/0890-4332(92)90016-B

[22] Prasad, B., Tiwari, G. N. "Analysis of double effect active solar distillation." Energy Conversion and Management. 37(11), pp. 1647-1656. 1996. https://doi.org/10.1016/0196-8904(95)00359-2

[23] Dev, R., Abdul-Wahab, S. A., Tiwari, G. N. "Performance study of the inverted absorber solar still with water depth and total dissolved solid." Applied Energy. 88(1), pp. 252-264. 2011. https://doi.org/10.1016/j.apenergy.2010.08.001

[24] Suneja, S., Tiwari, G. N. "Parametric study of an inverted absorber triple effect solar still." Energy Conversion and Management. 40(17), pp. 1871-1884. 1999. https://doi.org/10.1016/S0196-8904(99)00048-5

[25] Suneja, S., Tiwari, G. N., Rai, S. N. "Parametric study of an inverted absorber double-effect solar distillation system." Desalination. 109(2), pp. 177-186. 1997. https://doi.org/10.1016/S0011-9164(97)00063-5

[26] Tiris, C., Tiris, M., Erdalli, Y., Sohmen, M. "Experimental studies on a solar still coupled with a flat-plate collector and a single basin still." Energy Conversion and Management. 39, pp. 853-856. 1988. https://doi.org/10.1016/S0196-8904(97)83469-3

[27] Sandeep, Kumar, S., Dwivedi, V. K. "Experimental study on modified single slope single basin active solar still." Desalination. 367, pp. 69-75. 2015. https://doi.org/10.1016/j.desal.2015.03.031 
[28] Badran, A. A., Al-Hallaq, I. A., Eyal Salman, I. A., Odat, M. Z. "A solar still augmented with a flat-plate collector." Desalination. 172(3), pp. 227-234. 2005 .

https://doi.org/10.1016/j.desal.2004.06.203

[29] Badran, O. O., Al-Tahaineh, H. A. "The effect of coupling a flatplate collector on the solar still productivity." Desalination. 183(1-3), pp. 137-142. 2005.

https://doi.org/10.1016/j.desal.2005.02.046

[30] Kumar, S., Tiwari, G. N., Singh, H. N. "Annual performance of an active solar distillation system." Desalination. 127(1), pp. 79-88. 2000. https://doi.org/10.1016/S0011-9164(99)00194-0

[31] Singh, H. N., Tiwari, G. N. "Monthly performance of passive and active solar stills for different Indian climatic conditions." Desalination. 168, pp. 145-150. 2004.

https://doi.org/10.1016/j.desal.2004.06.180

[32] Rajaseenivasan, T., Nelson Raja, P., Srithar, K. "An experimental investigation on a solar still with an integrated flat plate collector." Desalination. 347, pp. 131-137. 2014.

https://doi.org/10.1016/j.desal.2014.05.029

[33] Eltawil, M. A., Omara, Z. M. "Enhancing the solar still performance using solar photovoltaic, flat plate collector and hot air." Desalination. 349, pp. 1-9. 2014.

https://doi.org/10.1016/j.desal.2014.06.021

[34] Morad, M. M., El-Maghawry, H. A. M., Wasfy, K. I. "Improving the double slope solar still performance by using flat-plate solar collector and cooling glass cover." Desalination. 373, pp. 1-9. 2015. https://doi.org/10.1016/j.desal.2015.06.017

[35] Arunkumar, T., Velraj, R., Denkenberger, D. C., Sathyamurthy, R., Vinoth Kumar, K., Ahsan, A. "Productivity enhancements of compound parabolic concentrator tubular solar stills." Renewable Energy. 88, pp. 391-400. 2016.

https://doi.org/10.1016/j.renene.2015.11.051

[36] Arunkumar, T., Velraj, R., Ahsan, A., Khalifa, A. J. N., Shams, S., Denkenberger, D., Sathyamurthy, R. "Effect of parabolic solar energy collectors for water distillation." Desalination and Water Treatment. 57(45), pp. 21234-21242. 2016.

https://doi.org/10.1080/19443994.2015.1119746

[37] Arunkumar, T., Vinothkumar, K., Ahsan, A., Jayaprakash, R., Kumar, S. "Experimental study on various solar still designs." ISRN Renewable Energy. 2012, p. 10. 2012. https://doi.org/10.5402/2012/569381

[38] Arunkumar, T., Denkenberger, D., Ahsan, A., Jayaprakash, R. "The augmentation of distillate yield by using concentrator coupled solar still with phase change material." Desalination. 314, pp. 189-192. 2013. https://doi.org/10.1016/j.desal.2013.01.018

[39] Elashmawy, M. "An experimental investigation of a parabolic concentrator solar tracking system integrated with a tubular solar still." Desalination. 411, pp. 1-8. 2017. https://doi.org/10.1016/j.desal.2017.02.003

[40] García-Rodríguez, L., Gómez-Camacho, C. "Design parameter selection for a distillation system coupled to a solar parabolic trough collector." Desalination. 122(2-3), pp. 195-204. 1999. https://doi.org/10.1016/S0011-9164(99)00041-7

[41] Scrivani, A., El Asmar, T., Bardi, U. "Solar trough concentration for fresh water production and waste water treatment." Desalination. 206(1-3), pp. 485-493. 2007. https://doi.org/10.1016/j.desal.2006.02.075

[42] Kumar, S., Sinha, S. "Transient model and comparative study of concentrator coupled regenerative solar still in forced circulation mode." Energy Conversion and Management. 37(5), pp. 629-636. 1996. https://doi.org/10.1016/0196-8904(95)00177-8
[43] Kabeel, A. E., Abdelgaied, M. "Observational study of modified solar still coupled with oil serpentine loop from cylindrical parabolic concentrator and phase changing material under basin." Solar Energy. 144, pp. 71-78. 2017.

https://doi.org/10.1016/j.solener.2017.01.007

[44] Kumar, S., Dubey, A., Tiwari, G. N. "A solar still augmented with an evacuated tube collector in forced mode." Desalination. 347, pp. 15-24. 2014. https://doi.org/10.1016/j.desal.2014.05.019

[45] Shafii, M. B., Shahmohamadi, M., Faegh, M., Sadrhosseini, H. "Examination of a novel solar still equipped with evacuated tube collectors and thermoelectric modules." Desalination. 382, pp. 21-27. 2016. https://doi.org/10.1016/j.desal.2015.12.019

[46] Omara, Z. M.,Eltawil, M. A., ElNashar, E. A. "A new hybrid desalination system using wicks/solar still and evacuated solar water heater." Desalination. 325, pp. 56-64. 2013.

https://doi.org/10.1016/j.desal.2013.06.024

[47] Panchal, H. N., Thakkar, H. "Theoretical and experimental validation of evacuated tubes directly coupled with solar still." Thermal Engineering. 63(11), pp. 825-831. 2016.

https://doi.org/10.1134/S0040601516110045

[48] Gorjian, S., Ghobadian, B., Hashjin, T. T., Banakar, A. "Experimental performance evaluation of a stand-alone point-focus parabolic solar still." Desalination. 352, pp. 1-17. 2014.

https://doi.org/10.1016/j.desal.2014.08.005

[49] Srithar, K.,Rajaseenivasan, T., Karthik, N., Periyannan, M., Gowtham, M. "Stand alone triple basin solar desalination system with cover cooling and parabolic dish concentrator." Renewable Energy. 90, pp. 157-165. 2016. https://doi.org/10.1016/j.renene.2015.12.063

[50] Arunkumar, T., Velraj, R., Denkenberger, D. C., Sathyamurthy, R. "Influence of crescent shaped absorber in water desalting system." Desalination. 398, pp. 208-213. 2016. https://doi.org/10.1016/j.desal.2016.07.039

[51] Velmurugan, V., Srithar, K. "Solar stills integrated with a mini solar pond - analytical simulation and experimental validation." Desalination. 216(1-3), pp. 232-241. 2007

https://doi.org/10.1016/j.desal.2006.12.012

[52] Velmurugan, V., Mandlin, J., Stalin, B., Srithar, K. "Augmentation of saline streams in solar stills integrating with a mini solar pond." Desalination. 249(1), pp. 143-149. 2009.

https://doi.org/10.1016/j.desal.2009.06.016

[53] El-Sebaii, A. A., Ramadan, M. R. I., Aboul-Enein, S., Salem, N. "Thermal performance of a single-basin solar still integrated with a shallow solar pond." Energy Conversion and Management. 49(10), pp. 2839-2848. 2008. https://doi.org/10.1016/j.enconman.2008.03.002

[54] El-Sebaii, A. A., Aboul-Enein, S., Ramadan, M. R. I., Khallaf, A. M. "Thermal performance of an active single basin solar still (ASBS) coupled to shallow solar pond (SSP)." Desalination. 280(1-3), pp. 183-190. 2011. https://doi.org/10.1016/j.desal.2011.07.004

[55] Kumar, P. N., Harris Samuel, D. G., Nagarajan, P. K., Sathyamurthy, R. "Theoretical analysis of a triangular pyramid solar still integrated to an inclined solar still with baffles." International Journal of Ambient Energy. 38(7), pp. 694-700. https://doi.org/10.1080/01430750.2016.1181569

[56] Eltawil, M. A., Zhengming, Z. "Wind turbine-inclined still collector integration with solar still for brackish water desalination." Desalination. 249(2), pp. 490-497. 2009.

https://doi.org/10.1016/j.desal.2008.06.029 
[57] Kumar, P. N., Manokar, A. M., Madhu, B., Kabeel, A. E., Arunkumar, T., Panchal, H., Sathyamurthy, R. "Experimental investigation on the effect of water mass in triangular pyramid solar still integrated to inclined solar still." Groundwater for Sustainable Development. 5, pp. 229-234. 2017. https://doi.org/10.1016/j.gsd.2017.08.003

[58] Yari, M., Mazareh, A. E., Mehr, A. S. "A novel cogeneration system for sustainable water and power production by integration of a solar still and PV module." Desalination. 398, pp. 1-11. 2016. https://doi.org/10.1016/j.desal.2016.07.004

[59] Kumar, S., Tiwari, A. "Design, fabrication and performance of a hybrid photovoltaic/thermal (PV/T) active solar still." Energy Conversion and Management. 51(6), pp. 1219-1229. 2010. https://doi.org/10.1016/j.enconman.2009.12.033

[60] Kumar, B. P., Winston, D. P., Pounraj, P., Manokar, A. M., Sathyamurthy, R., Kabeel, A. E. "Experimental investigation on hybrid PV/T active solar still with effective heating and cover cooling method." Desalination. 435, pp. 140-151. 2018. https://doi.org/10.1016/j.desal.2017.11.007

[61] Shukla, S. K., Sorayan, V. P. S. "Thermal modeling of solar stills: an experimental validation." Renewable Energy. 30(5), pp. 683-699. 2005. https://doi.org/10.1016/j.renene.2004.03.009

[62] Zurigat, Y. H., Abu-Arabi, M. K. "Modelling and performance analysis of a regenerative solar desalination unit." Applied Thermal Engineering. 24(7), pp. 1061-1072. 2004.

https://doi.org/10.1016/j.applthermaleng.2003.11.010
[63] Velmurugan, V., Gopalakrishnan, M., Raghu, R., Srithar, K. "Single basin solar still with fin for enhancing productivity." Energy Conversion and Management. 49(10), pp. 2602-2608. 2008.

https://doi.org/10.1016/j.enconman.2008.05.010

[64] Velmurugan, V., Naveen Kumar, K. J., Noorul Haq, T., Srithar, K. "Performance analysis in stepped solar still for effluent desalination." Energy. 34(9), pp. 1179-1186. 2009. https://doi.org/10.1016/j.energy.2009.04.029

[65] Velmurugan, V., Deenadayalan, C. K., Vinod, H., Srithar, K. "Desalination of effluent using fin type solar still." Energy. 33(11), pp. 1719-1727. 2008. https://doi.org/10.1016/j.energy.2008.07.001

[66] Srithar, K., Mani, A. "Comparison between simulated and experimental performance of an open solar flat plate collector for treating tannery effluent." International Communications in Heat and Mass Transfer. 30(4), pp. 505-514. 2003. https://doi.org/10.1016/S0735-1933(03)00079-4

[67] El-Sebaii, A. A., Al-Ghamdi, A. A., Al-Hazmi, F. S., Faidah, A. S. "Thermal performance of a single basin solar still with PCM as a storage medium." Applied Energy. 86(7-8), pp. 1187-1195. 2009. https://doi.org/10.1016/j.apenergy.2008.10.014

[68] Watmuff, J. H., Charters, W. W. S., Proctor, D. "Solar and wind induced external coefficients-solar collectors." Cooperation Mediterraneenne pour l'Energie Solaire. 56, 1977. 